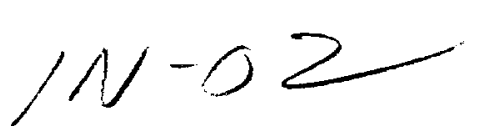

NASA Technical Memorandum 107400

AIAA-97-0052

\title{
Characterization of Ice Roughness From Simulated Icing Encounters
}

David N. Anderson and J. Shin

Lewis Research Center

Cleveland, Ohio

Prepared for the

35th Aerospace Sciences Meeting \& Exhibit

sponsored by the American Institute of Aeronautics and Astronautics

Reno, Nevada, January 6-10, 1997

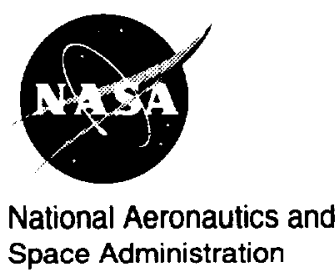




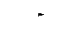

. 
Characterization of Ice Roughness from Simulated Icing Encounters

\author{
David N. Anderson \\ and \\ Jaiwon Shin \\ National Aeronautics and Space Administration \\ Lewis Research Center \\ Cleveland, Ohio 44135
}

\begin{abstract}
Detailed measurements of the size of roughness elements on ice accreted on models in the NASA Lewis Icing Research Tunnel (IRT) were made in a previous study. Only limited data from that study have been published, but included were the roughness element height, diameter and spacing. In the present study, the height and spacing data were found to correlate with the element diameter, and the diameter was found to be a function primarily of the non-dimensional parameters freezing fraction and accumulation parameter. The width of the smooth zone which forms at the leading edge of the model was found to decrease with increasing accumulation parameter. Although preliminary, the success of these correlations suggests that it may be possible to develop simple relationships between ice roughness and icing conditions for use in ice-accretionprediction codes. These codes now require an iceroughness estimate to determine convective heat transfer. Studies using a 7.6-cm-diameter cylinder and a 53.3-cm-chord NACA 0012 airfoil were also performed in which a $1 / 2$-min icing spray at an initial set of conditions was followed by a $91 / 2$-min spray at a second set of conditions. The resulting ice shape was compared with that from a full 10-min spray at the second set of conditions. The initial ice accumulation appeared to have no effect on the final ice shape. From this result, it would appear that accreting ice is affected very little by the initial roughness or shape features.
\end{abstract}

\section{Nomenclature}

$A_{c} \quad$ Accumulation parameter, dimensionless

$b$ Relative heat factor, dimensionless

c Airfoil leading-edge or cylinder diameter, $\mathrm{cm}$

$c_{p, c} \quad$ Specific heat of $\mathrm{air}, \mathrm{cal} / \mathbf{g} \mathrm{K}$

$c_{p, w} \quad$ Specific heat of water, $\mathrm{cal} / \mathrm{g} \mathrm{K}$

d Roughness-element diameter, $\mathrm{cm}$

evap Evaporation terms in energy equation, ${ }^{\circ} \mathrm{C}$

$h$ Roughness-element height, $\mathrm{cm}$

$h_{c} \quad$ Convective heat-transfer coefficient, $\mathrm{cal} / \mathrm{s} \mathrm{cm}^{2} \mathrm{~K}$
LWC Cloud liquid-water content, $\mathrm{g} / \mathrm{m}^{3}$

MWD Water droplet median volume diameter, $\mu \mathrm{m}$

$n \quad$ Freezing fraction, dimensionless

$s \quad$ Spacing between roughness elements, $\mathrm{cm}$

$V \quad$ Airspeed, $\mathrm{m} / \mathrm{s}$

$t_{f} \quad$ Freezing temperature of water, ${ }^{\circ} \mathrm{C}$

$t_{\operatorname{maf}} \quad$ Temperature at surface of ice, ${ }^{\circ} \mathrm{C}$

$t_{*} \quad$ Static temperature, ${ }^{\circ} \mathrm{C}$

tool Total temperature, ${ }^{\circ} \mathrm{C}$

w Smooth-zone width, $\mathrm{cm}$

$\beta_{0} \quad$ Stagnation-zone droplet collection efficiency, dimensionless

$\delta \quad$ Droplet median volume diameter, $\mu \mathrm{m}$

$\phi$ Droplet energy transfer terms in energy balance, ${ }^{\circ} \mathrm{C}$

$A_{f} \quad$ Latent heat of freezing of water, $\mathrm{cal} / \mathrm{g}$

$\rho_{i} \quad$ Ice density, $g / \mathrm{m}^{3}$

$\theta$ Air energy transfer terms in energy balance, ${ }^{\circ} \mathrm{C}$

\section{Introduction}

This paper presents the results of a study of the effects and characteristics of the roughness which forms on the surface of a glaze-ice accretion. The freezing rate of water impinging to form glaze ice is strongly dependent on the rate of heat transfer. Because surface roughness is known to have an important effect on the convective heat transfer, an estimate of the roughness size is presently used to establish heat-transfer coefficients in ice-accretion prediction codes such as the NASA Lewis LEWICE code ${ }^{1,2}$. In this paper, correlations of measurements of roughness made by $\mathrm{Shin}^{3}$ will be presented. In addition, the effect of initial ice roughness and ice formation on the final ice shape was explored, and these results will be presented.

In the past few years a number of studies have been made to try to understand the physical processes which occur during an icing encounter of an aircraft in flight. 
This interest in icing physics has been a response to the need to improve the predictive capability of analytical ice-accretion models such as the NASA Lewis LEWICE ${ }^{1,2}$ code.

The first of these studies was made by Olsen and Walker ${ }^{4,5}$ who studied ice accretion with high-speed motion pictures. Based on their observations, they questioned the traditional model of ice accretion proposed by Messinger ${ }^{6}$ in 1953 . The Messinger model for glaze ice assumed that water which did not freeze on impact ran back along the surface to freeze farther back. Olsen and Walker observed no runback of a liquid film, but rather noticed that unfrozen water coalesced into beads on the surface. These beads subsequently froze into closely spaced, approximately hemispherical roughness elements. In the earty stages of icing exposure, a relatively smooth zone at the leading edge of the test model was also observed; this zone extended back some distance until a sudden transition to the rough zone occurred.

Additional close-up studies of ice accretion were later performed by Hansman, Reehorst and Sims ${ }^{7}$ using high-speed video techniques. They noted the formation of a thin rime ice layer on the surface of the model when icing started. This phenomenon was attributed to conduction heat transfer into the model, so its occurrence could be dependent on model construction. The authors pointed out that once such a layer had formed, any subsequent ice formation would be unaffected by the model surface treatment (polishing, waxing, etc.) that might be done to influence the initial bead formation of water. The growth of water beads through coalescence was noted to occur until the bead was sufficiently large to be influenced by aerodynamic forces. When this occurred, the bead was suddenly swept downstream where it froze.

The subsequent freezing observed in reference 7 was attributed to a higher heat transfer rate where the boundary layer was tripped. However, Bragg and $c^{\circ-}$ workers $^{89}$ found that roughness elements of the size measured by $\mathrm{Shin}^{3}$ did not cause immediate transition of the boundary layer from laminar to turbulent. Instead, while the transition began at the edge of the rough zone, significant distance along the surface was required before fully turbulent flow was established well back on the airfoil.

The formation of the hemispherical beads of roughness through coalescence of liquid water on the surface of the ice would be strongly influenced by water surface tension. Hansman and Turnock ${ }^{10,11}$ studied bead for- mation with water and with a water-surfactant mixture. The addition of surfactant to the spray water reduced the surface tension of the water by a factor of 2 and produced smaller beads. The final ice formation which resulted with surfactant addition was opaque and had more distinct horns than that from untreated water. Similar results with surfactant were reported by others. ${ }^{12}$ These studies suggested that surface effects, in addition to convective heat transfer, may have a strong influence on the final ice shape. Surface phenomena are outside the scope of this paper, but deserve more investigation.

The LEWICE ${ }^{2}$ ice-accretion code currently estimates the roughness element size by balancing aerodynamic forces, which tend to move the droplet along the surface, with surface-tension forces, which tend to restrain the droplet motion. The roughness size is then used to determine the convective heat transfer. Shin's ${ }^{3}$ objective was to establish relationships between icing conditions and the roughness characteristics. If the roughness correlated with icing conditions in a simple way, the roughness size could be calculated from the correlations in the LEWICE code. Because the present paper draws heavily on the work of Shin, that research and its results will be discussed in the next section in some detail.

It has been speculated that the initial roughness which forms during ice accretion may have a strong effect on the final ice shape. Roughness features could provide locally enhanced collection efficiencies for water droplet impingement, and they would also tend to increase the local heat transfer for higher freezing rates. In this way, small roughness features would grow rapidly, they would dominate the accretion process and determine the final ice shape. Hansman and Turnock" " however, found that, "as the accretion grows, the effect of initial conditions begins to wash out," and the initial surface condition had no effect on final ice shape. The second objective of the present study, then, was to explore further the effect of initial roughness on final ice shape.

The present study used a 7.6-cm- (3-in-) diameter hollow aluminum cylinder and a $53.3-\mathrm{cm}-(21-$ in-) chord solid aluminum NACA 0012 airfoil to study the effect of initial spray conditions on final ice shape. Ice shapes were recorded for 10-min sprays in which the initial $1 / 2$ min was at a different set of conditions from the final $91 / 2$. These shapes were compared with those obtained for a full 10-min spray at the final set of conditions. Icing conditions included static temperatures of $-6^{\circ} \mathrm{C}$ to $-1^{\circ} \mathrm{C}\left(21^{\circ} \mathrm{F}\right.$ to $\left.30^{\circ} \mathrm{F}\right)$, airspeeds of 67 and 89 
$\mathrm{m} / \mathrm{s}$ (150 and $200 \mathrm{mph}$ ), a median volume diameter drop size of $20 \mu \mathrm{m}$ and liquid-water contents of .5 and $1 \mathrm{~g} / \mathrm{m}^{3}$. Tests were performed in the NASA Lewis Icing Research Tunnel (IRT).

\section{Correlations from Shin's ${ }^{3}$ Study}

Shin used both a digital and 35-mm camera to photograph the roughness characteristics on the leading edge of a $53.3-\mathrm{cm}-(21-\mathrm{in}-)$ chord NACA 0012 airfoil after sprays of 1 to 3 minutes in conditions which would produce glaze ice. All tests were made in the IRT.

Figure 1 is a sketch which shows features of a typical glaze-ice accretion beginning to form after a short exposure to an icing spray. From digital photographs of such ice accretions for a variety of test conditions and exposure times Shin found that the ice-roughness elements took the form of hemispheres on the surface of an ice substrate. These roughness elements formed some distance back from the leading edge leaving a smooth zone whose width decreased with exposure time. Shin measured the diameter, $d$, height, $h$, and spacing, $s$ to characterize the element roughness and recorded the width, $w$, of the smooth zone.

Figure 2 shows how the roughness-element spacing, $s$, and height, $h$, correlate with the diameter, $d$. The ele-

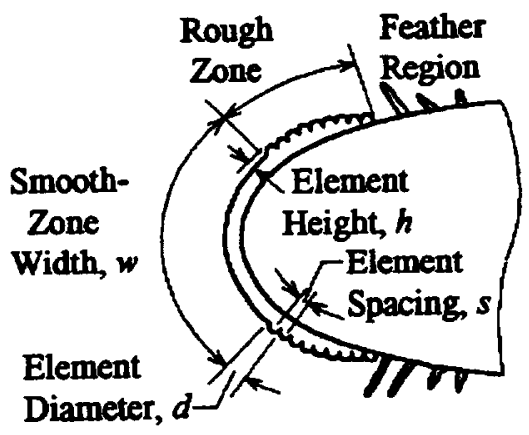

Figure 1. Roughness Features on Leading Edge of Airfoil.

ments almost touched so that the spacing was slightly greater than one diameter. The height was approximately one-half the diameter. Because of the strong correlation of spacing and height with the diameter shown in Figure 2, it should be adequate to use simply the diameter to describe the effects of icing conditions on the roughness characteristics. The roughness characteristics measured by Shin often differed significantly from those predicted by the then-current version of the LEWICE code; and this result further empha- sized the importance of developing a good understanding of how roughness forms.

Shin showed that ice roughness element size grew with time up to $2 \mathrm{~min}$, then became constant. A reasonable postulation is that the size of the coalesced beads is determined by the rates of water impingement and freezing. For a given rate of water accumulation, a high rate of freezing would halt the growth of beads at a smaller size than would occur with a low rate of freezing. With low freezing rates, the bead size may be limited by the boundary-layer thickness: Beads which grow sufficiently to protrude from the boundary layer are subjected to aerodynamic forces which would tend to sweep them downstream, as observed in the studies of references 4,5 and 7. In the present work, no attempt was made to relate roughness size with boundary-layer thickness; instead, Shin's roughness dimensions will be shown here to be correlated with the nondimensional terms familiar to icing research, accumulation parameter and freezing fraction.

The accumulation parameter is a non-dimensional parameter which is proportional to the rate at which ice accretes. It is given by

$$
A_{c}=\frac{V \cdot L W C \cdot \tau}{c \cdot \rho_{i}}
$$

The freezing fraction was defined by Messinger ${ }^{6}$ as the fraction of water which froze in the region of impingement. Its value can be found from an energy balance made on the surface at the leading edge of a model exposed to an icing cloud:

$$
n=\frac{c_{p, w}}{\Lambda_{f}}\left(\phi+\frac{\theta}{b}\right)
$$

where $\phi$ is a collection of terms representing the droplet energy transfer:

$$
\phi=t_{f}-t_{s t}-\frac{V^{2}}{2 c_{p, w}}
$$

and $\theta$ represents the air energy transfer:

$$
\theta=t_{\text {surf }}-t_{\star x}-r \frac{V^{2}}{2 c_{p, a}}+e v a p
$$


where evap represents a water evaporation term, which is usually small. Both $\phi$ and $\theta$ have units of temperature. $b$ is a non-dimensional term called the relative heat factor, it is the ratio of the heat carried to the surface by impinging water to that convected away by the airstream. It is defined as:

$$
b=\frac{L W C \cdot V \cdot \beta_{0} \cdot c_{p, w}}{h_{c}}
$$

The effect of accumulation parameter on roughness size is given in figure 3 . For data with a freezing fraction of approximately .3 , Shin's data indicated that the roughness size increased linearly with accumulation parameter until $A_{c}$ reached a value of .1 ; for $A_{c}$ greater than .1 , element size was nearly constant.

In figure 4 roughness-element diameters resulting from tests with $A_{\varepsilon}>.1$ (i.e., diameter independent of $A_{\varepsilon}$ ) have been plotted as a function of the freezing fraction. Roughness size decreased with increasing freezing fraction, with the rate of decrease greatest at the lowest freezing fractions.

Finally, Shin's smooth-zone width has been correlated with the accumulation parameter in Figure 5. For these conditions, the smooth-zone width was found to decrease linearly with accumulation parameter. The mechanism by which the smooth zone contracts has not yet been fully explained. The data in Figure 5 were for a freezing fraction of .3; insufficient data exists to determine if other values of freezing fraction would give different correlations.

\section{Description of Experiments}

\section{NASA Lewis Icing Research Tunnel The IRT is} shown in Figure 6 . It has been described in reference 13. The IRT has a test section width of $2.7 \mathrm{~m}(9 \mathrm{ft})$ and a height of $1.8 \mathrm{~m}(6 \mathrm{ft}$ ) It is capable of operation at test-section airspeeds up to $160 \mathrm{~m} / \mathrm{s}$ (350 mph) with a blockage of $5 \%$ in the test section. A refrigeration system permits accurate control of the test-section temperature from -30 to $1^{\circ} \mathrm{C}\left(-20\right.$ to $\left.33^{\circ} \mathrm{F}\right)$ within $\pm .5^{\circ} \mathrm{C}$ ( $\pm 1 \%$ F). A water-spray system with 8 spray bars has been calibrated to provide controlled test-section liquid-water contents from .2 to $3 \mathrm{~g} / \mathrm{m}^{3}$ and droplet median volume diameters from 15 to $40 \mu \mathrm{m}$.

Two sets of spray nozzles, known as the mod-1 and standard nozzles, are used in the IRT to provide different ranges of liquid-water content and droplet size ${ }^{13}$.
For the tests of this study, only the mod-1 nozzles were used.

Test Models Two models were used to shudy the effect of initial ice roughness on final ice shape. The first was a 7.6-cm- (3-in-) diameter hollow aluminum cylinder. The cylinder was mounted on stands in the center of the IRT test section as shown in figure 7. To permit the IRT spray-bar conditions to reach steadystate before exposing the model to the icing cloud and, thus, to control the exposure time precisely, a shield was lowered in front of the model as shown in the figure. Once the spray had stabilized, the shield was raised; the exposure time was counted from the raising of the shield to the completion of the spray.

The second model which was used to look at the effect of initial roughness was a 53.3-cm (21-in) NACA 0012 airfoil mounted vertically in the center of the IRT test section. It was a 1.8-m- (6-ft-) span model machined from solid aluminum.

Figure 8(a) shows the airfoil installed in the test section. The model was mounted to the IRT turntable at its base and to the ceiling with a pivot. Although this mounting gave the capability of varying angle of attack, all tests were run at $0^{\circ}$. The metal shield described above for the cylinder tests could not be used with this airfoil because of mounting constraints. Instead, a fabric shield was attached to the leading edge with velcro fasteners as shown in Figure 8(b). A rope attached to the fabric was passed through a hole in the tunnel ceiling. When spray conditions had stabilized, the rope was manually jerked to pull the shield clear of the model. An advantage of this method of protecting the airfoil during spray stabilization was that the testsection blockage was unchanged when the protection was removed; consequently, the test-section velocity remained constant.

Total Temperature Measurement The IRT total temperature is measured as the average of 11 type-T thermocouples distributed over the downstream plane of the corner-D turning vanes. Comer $D$ is just upstream of the spray bars. In addition to these measurements, a heated Rosemount total-temperature probe was mounted on a borizontally traversing mechanism mounted just downstream of the test section for the airfoil tests. This probe was located to sense the temperature mid way between the floor and ceiling of the tunnel. The probe was traversed across the tunnel before and after selected tests to calibrate the corner-D average temperatures with the actual test-section temperature. The traversing temperature probe was found 
to be consistent with the corner- $D$ average temperature. For the airfoil tests only, the corner-D temperatures were recorded every $2 \mathrm{sec}$ throughout each test. Average run temperatures were then computed. These averages agreed with the temperature set by the tunnel operators within $\pm 3^{\circ} \mathrm{C}\left(.5^{\circ} \mathrm{F}\right)$. Because of this close agreement, the test temperature reported here is the temperature requested of the tunnel operators.

The thermocouple readings were considered accurate to within $\pm 5^{\circ} \mathrm{C}\left(1{ }^{\circ} \mathrm{F}\right)$. With possible additional discrepancy between the requested and actual average run temperatures of $\pm 3^{\circ} \mathrm{C}\left(.5^{\circ} \mathrm{F}\right)$, the total uncertainty in temperature was about $\pm 8^{\circ} \mathrm{C}\left(1.4^{\circ} \mathrm{F}\right)$.

Test-Section Velocity Measurement The IRT uses two pitot-static probes, one on each side of the entrance to the test section, to determine velocity. For the airfoil tests, the total and static pressures from each probe were recorded at 2-sec intervals during each test. The test-section velocity was calculated from the pressures for each probe at each recording interval. The runaverage velocity for each probe was then obtained, and these two velocities were averaged to give the testsection free-stream velocity. The individual averages found from the two probes differed consistently by about $1 \mathrm{~m} / \mathrm{s}(2 \mathrm{mph})$. Considering the accuracy of the transducers along with this uncertainty gives an estimated uncertainty in the velocity measurement of less than $\pm 4 \%$. The measured average test section velocity never differed from the requested set point by more than $.5 \mathrm{~m} / \mathrm{s}(1 \mathrm{mph})$; thus, the velocities reported will be the set conditions.

Spray-Bar Conditions The IRT is routinely calibrated on a regular basis. The cloud median volume diameter (MVD) and liquid-water content ( $L W C$ ) were determined by applying this calibration to measured spraybar water and air pressures. For the airfoil tests, pressures were recorded at 2-sec intervals, the $M V D$ and $L W C$ calculated from the pressures at each interval and, finally, the average nun $M V D$ and $L W C$ computed. These average run values agreed with the requested values typically within $1 \%$, so the requested values will be reported here for all tests. Considering both the inaccuracy of the transducers used in the measurements and the fluctuations with time, the typical uncertainty in the liquid-water content was found to be less than \pm $2.2 \%$ and in the median volume diameter, less than \pm $12.7 \%$.

Test Procedure Tests were performed by first establishing the desired test-section velocity and temperature. For the cylinder tests, the remotely-operated shield was lowered in front of the model at this point; the airfoil shield was manually placed on the model before starting the tunnel fan. Water spray was then initiated. The shield was raised when the spray conditions had stabilized, and spray timing was started.

To determine the effect of initial roughness on the final ice shape, a series of paired tests were performed. For the first test of the pair, an initial $1 / 2$-min accretion was allowed to form on the model followed by a $91 / 2$-min accretion with conditions sufficiently different from the initial to give different freezing fractions and, thus, roughness sizes. The second test of the pair used the final conditions from the first test for the full 10-min spray. In effect, then, the initial $1 / 2$-min roughness for the two tests should have been different. The final 10min ice shapes for each test were compared.

The tests were performed by shielding the model after the initial $1 / 2-\min$ spray of the first test of the pair. The shield was dropped in front of the model remotely for the cylinder, but for the airfoil tests, the tunnel was brought to idle to permit personnel entry to the test section to place the shield on the model. The second set of tunnel conditions was then established, and, once the new conditions had stabilized, the shield was lifted to expose the model to the second set of conditions for the additional $91 / 2 \mathrm{~min}$. The tunnel was brought to idle, the final ice shape was recorded and the model cleaned. For the second test run of the pair, the second set of tunnel conditions was used without interruption for a full 10-min icing exposure and the ice shape again recorded. After the ice shape was recorded, the model was cleaned and the procedure repeated for the next spray series.

The ice shape was recorded by melting a thin gap through the ice normal to the model span-wise axis. The shape was then traced onto a cardboard template. All ice shapes presented here were taken midway between the floor and ceiling of the tunnel. These shapes were later digitized for computer storage of the coordinates for preparation of comparison plots.

\section{Effect of Initial Accretion on Final Ice Shape}

In this section, the ice shapes will be compared for the tests with alternate initial spray conditions.

Cylinder Tests The first series of tests were performed using the 7.6-cm-diameter cylinder and metal shield described above. 
In figure 9 the effect of changing the liquid-water content is shown. All accretions for the tests of Figure 9 were made with a static temperature of $4^{\circ} \mathrm{C}\left(24^{\circ} \mathrm{F}\right)$, a velocity of $67 \mathrm{~m} / \mathrm{s}$ (150 mph) and a median volume drop diameter of $20 \mu \mathrm{m}$. In 9(a) an ice shape produced by spraying with a liquid-water content of $1 \mathrm{~g} / \mathrm{m}^{3}$ for $1 / 2$ min followed by $.5 \mathrm{~g}^{3} \mathrm{~m}^{3}$ for $91 / 2 \mathrm{~min}$ is compared with two shapes with $L W C$ of $.5 \mathrm{~g} / \mathrm{m}^{3}$ for $10 \mathrm{~min}$. Comparison of the latter two ice shapes gives some indication of the repeatability of shapes when the same conditions are specified in the IRT. Within normal repeatability of ice shapes, there appeared to be no effect of the initial 1/2-min spray on the final shape. In 9(b), the initial $1 / 2$-min spray had an $L W C$ of $1 \mathrm{~g}^{3} \mathrm{~m}^{3}$, followed by .5 $\mathrm{g} / \mathrm{m}^{3}$ for $91 / 2 \mathrm{~min}$. This shape is compared in the figure with one produced with a 10 -min spray at $1 \mathrm{~g} / \mathrm{m}^{3}$.

Again, there was no significant difference in ice shape.

The freezing fraction was estimated to be .20 for the tests with a liquid-water content of $1 \mathrm{~g} / \mathrm{m}^{3}$, and .35 at $.5 \mathrm{~g}^{3} \mathrm{~m}^{3}$. From Figure 4, these freezing fractions suggest that the $L W C$ of $1 \mathrm{~g} / \mathrm{m}^{3}$ would produce a roughness about $25 \%$ higher than the $.5-\mathrm{g} / \mathrm{m}^{3}$ condition. A comparison of the ice shapes produced by the .5- and 1$\mathrm{g} / \mathrm{m}^{3}$ conditions in Figures 9 (a) and (b) shows a significant difference; yet, in each case, the initial $1 / 2$-min spray condition had no effect on the final ice shape.

The effect of icing with two temperatures is illustrated in figure 10 . The accretions were made with a velocity of $67 \mathrm{~m} / \mathrm{s}$ (150 mph), a median volume drop diameter of $20 \mu \mathrm{m}$ and a liquid-water content of $.5 \mathrm{~g} / \mathrm{m}^{3}$. The first ice shape in figure 10 (a) had an initial $1 / 2$-min spray at $-6^{\circ} \mathrm{C}\left(21^{\circ} \mathrm{F}\right)$ static temperature $(n=.51)$ followed by $91 / 2 \mathrm{~min}$ at $4^{\circ} \mathrm{C}\left(24^{\circ} \mathrm{F}\right)(n=.35)$. This shape is compared with two made with 10-min sprays at a constant $-4^{\circ} \mathrm{C}$. The latter two shapes indicated that the ability to repeat ice shapes at this condition was quite good. The effect of the $-6^{\circ} \mathrm{C}$ initial spray appeared to be insignificant in determining the final ice shape.

Figure 10(b) shows ice shapes accreted for the same conditions of 10(a) except that the spray-condition sequence was reversed, with the first shape made with a spray at $-4^{\circ} \mathrm{C}\left(24^{\circ} \mathrm{F}\right)$ for $1 / 2 \mathrm{~min}$ followed by $-6^{\circ} \mathrm{C}$ $\left(21^{\circ} \mathrm{F}\right)$ for $91 / 2 \mathrm{~min}$. This shape only approximates that from a 10 -min spray at $-6^{\circ} \mathrm{C}$. The reason for this poor match is not apparent but will be discussed further after presenting additional cylinder test results.

In the next series of tests, static temperatures of -6 and $-3^{\circ} \mathrm{C}\left(21\right.$ and $\left.26^{\circ} \mathrm{F}\right)$ were used. Test results are reported in Figures 10(c) and 10(d) for sprays with the same velocity, $M N D$, and $L W C$ as used in Figures 10(a) and (b). In 10(c), the first shape resulted from an initial $1 / 2-\min$ spray at a static temperature of $-6^{\circ} \mathrm{C}(n=$ .51) followed by $91 / 2 \mathrm{~min}$ at $-3^{\circ} \mathrm{C}(n=.24)$. The comparison with a shape produced with a 10-min spray at $3^{\circ} \mathrm{C}$ is again very good. Reasonable, although not perfect, agreement was found between an ice shape generated with an initial spray at $-3^{\circ} \mathrm{C}$ for $1 / 2$ min then $6^{\circ} \mathrm{C}$ for an additional $9 \frac{1}{2} \mathrm{~min}$ and a shape from a 10 min spray at $-6^{\circ} \mathrm{C}$ (figure $10(d)$.)

Both Figures 10(b) and 10(d) represent cases in which a low-freezing-fraction spray was followed by a higher one. In cach case, the ice-shape did not fully match that for a 10-min spray at the higher freezing fraction. This result might suggest that the larger roughness elements produced at the lower freezing fraction had a discernible effect on the final shape. However, Figure 9(a) showed that a $1 / 2-$ min spray with a freezing fraction of .2 followed by $91 / 2 \mathrm{~min}$ at $n=.35$ produced a shape which was an excellent match for a 10-min shape at $n=.35$. Furthermore, the shapes of Figure 10(d) are a better match than those of 10 (b) even though the freezing-fraction difference for the 10(d) tests was greater. Thus, further studies are needed to determine if the unmatched ice shapes seen in Figures 10(b) and (d) are repeatable, and, if so, to establish a physical explanation.

Airfoil Tests The second group of tests used the 53.3cm- (21-in-) chord NACA 0012 airfoil with the fabric shield. The test procedure was the same as for the cylinder tests, except that the fabric shield had to be manually placed over the $1 / 2$-min ice formation at the end of the initial spray. Shield removal involved jerking it away using an attached rope as described above in the Description of Experiments section. This action could potentially have damaged the initial ice formation as the fabric tended to drag over the surface. To evaluate the possible extent of disturbance, a few trials were made in which the ice was observed before and after shield removal. No visual effect was apparent.

The ice-shape comparisons for the airfoil tests are given in Figure 11. All tests reported in this figure used an $M W D$ of $20 \mu \mathrm{m}$ and an $L W C$ of $.5 \mathrm{~g} / \mathrm{m}^{3}$. Figure 11(a) compares a 10-min ice shape made at a temperature of $-6^{\circ} \mathrm{C}\left(21^{\circ} \mathrm{F}\right)$ with the shape resulting from first spraying at $-3^{\circ} \mathrm{C}\left(26^{\circ} \mathrm{F}\right)$ for $1 / 2$ min then spraying at $-6^{\circ} \mathrm{C}\left(21^{\circ} \mathrm{F}\right)$ for $91 / 2 \mathrm{~min}$. All temperatures quoted are the static temperatures, and the velocity was $67 \mathrm{~m} / \mathrm{s}$ (150 mph) for all the sprays of Figure 11(a). The freezing fraction for these conditions was estimated to be .58 at $-6^{\circ} \mathrm{C}\left(21^{\circ} \mathrm{F}\right)$ and .27 at $-3^{\circ} \mathrm{C}\left(26^{\circ} \mathrm{F}\right)$. Reference to Figure 4 suggests that these freezing fractions could 
have given a $30-40 \%$ difference in surface roughness. Here, again, in contrast with the results of Figures 10(b) and (d) the test with the high initial roughness gives a shape which matches a test with a low initial roughness.

Figure 11(b) looks at the effect of changing the testsection velocity during the spray. For these tests, the static temperature was maintained at $-6^{\circ} \mathrm{C}\left(21^{\circ} \mathrm{F}\right)$. The initial $1 / 2$-min spray was made with a test-section velocity of $67 \mathrm{~m} / \mathrm{s}(150 \mathrm{mph})$. This was followed by a $91 / 2$-min spray at $89 \mathrm{~m} / \mathrm{s}(200 \mathrm{mph})$. The final ice shape from these sprays is compared with a 10-min spray at $89 \mathrm{~m} / \mathrm{s}(200 \mathrm{mph})$. The lower velocity gave a freezing fraction of about .58 at these conditions, and the higher velocity, $n=.40$. The correlation of Figure 4 suggests that roughness size may differ by about $30 \%$. Again, no effect of initial spray conditions on final ice shape was evident.

\section{Concluding Remarks}

In general, this study showed that 10-min ice shapes appear to be independent of initial $1 / 2$-min icing conditions. This finding is consistent with the observations of Hansman and Turnock, ${ }^{11}$ who found that ice shapes accreted on surfaces of different materials were the same. The initial ice features are covered by subsequent accretion and do not appear to influence later accretions significantly. The final ice shape appeared to be determined by the spray conditions at which the dominant accumulation occurred.

Using limited data from $\mathrm{Shin}^{3}$, this paper successfully correlated roughness size with freezing fraction and accumulation parameter. If such correlations are possible, they can be readily incorporated into iceaccretion-prediction codes to permit accurate convective heat-transfer coefficient determination for any specified icing condition. At present, such codes must rely on estimates of roughness size to determine heat transfer. The correlations presented here are based on limited data and are preliminary. Additional roughness data are needed for confirmation.

\section{References}

1. Ruff, G.A. and Berkowitz, B., 'User's Manual for the NASA Lewis Ice Accretion Prediction Code LEWICE," NASA CR 185129, May 1990.
2. Wright, William B., "Users Manual for the Improved NASA Lewis Ice Accretion Code LEWICE 1.6," NASA Contractor Report 198355, June, 1995.

3. Shin, Jaiwon, "Characterization of Surface Roughness Associated with Leading Edge Ice Accretion," NASA TM 106459 and AIAA 94-0799, January, 1994.

4. Olsen, W. and Walker, E., "Close up Motion Pictures of the Icing Process," NASA LeRC Film, 1983.

5. Olsen, W.A. and Walker, E., "Experimental Evidence for Modifying the Current Physical Model for Ice Accretion on Aircraft Structures," NASA TM 87184, 1987.

6. Messinger, B.L., "Equilibrium Temperature of an Unheated Icing Surface as a Function of Airspeed," J. Aeron. Sci. 20 No. 1, Jan. 1953, pp 29-42.

7. Hansman, R John, Jr., Reehorst, Andrew and Sims, James, "Analysis of Surface Roughness Generation in Aircraft Ice Accretion," AIAA-92-0298, January, 1992.

8. Bragg, M.B., Kerho, M. and Cummings, M., "Airfoil Boundary Layer Due to Large Leading-Edge Rougness," AIAA-95-0536, January, 1995.

9. Bragg, M.B., Cummings, M.J., Lee, S. and Henze, C.M., "Boundary-Layer and Heat-Transfer Measurements on an Airfoil with simulated Ice Roughness," AlAA-96-0866, January, 1996.

10. Hansman, R. John, Jr., and Turnock, Stephen R, "Investigation of Microphysical Factors Which Influence Surface Roughness During Glaze Ice Accretion," 4th International Workshop on Atmospheric Icing of Structures, Sept. 1988, Paris.

11. Hansman, R.J., Jr. and Turnock, S.R, "Investigation of Surface Water Behavior During Glaze Ice Accretion," J Aircraft 26, no 2, February 1989, pp 140-147.

12. Bilanin, Alan J. and Anderson, David N.: "Ice Accretion with Varying Surface Tension," AIAA 950538 and NASA TM 106826, January, 1995.

13. Soeder, Ronald H., Sheldon, David W., Andracchio, Charles, R., Ide, Robert F., Spera, David A. and Lalii, Nick M., "NASA Lewis Icing Research Tunnel User Manual," NASA TM 107159, June 1996. 


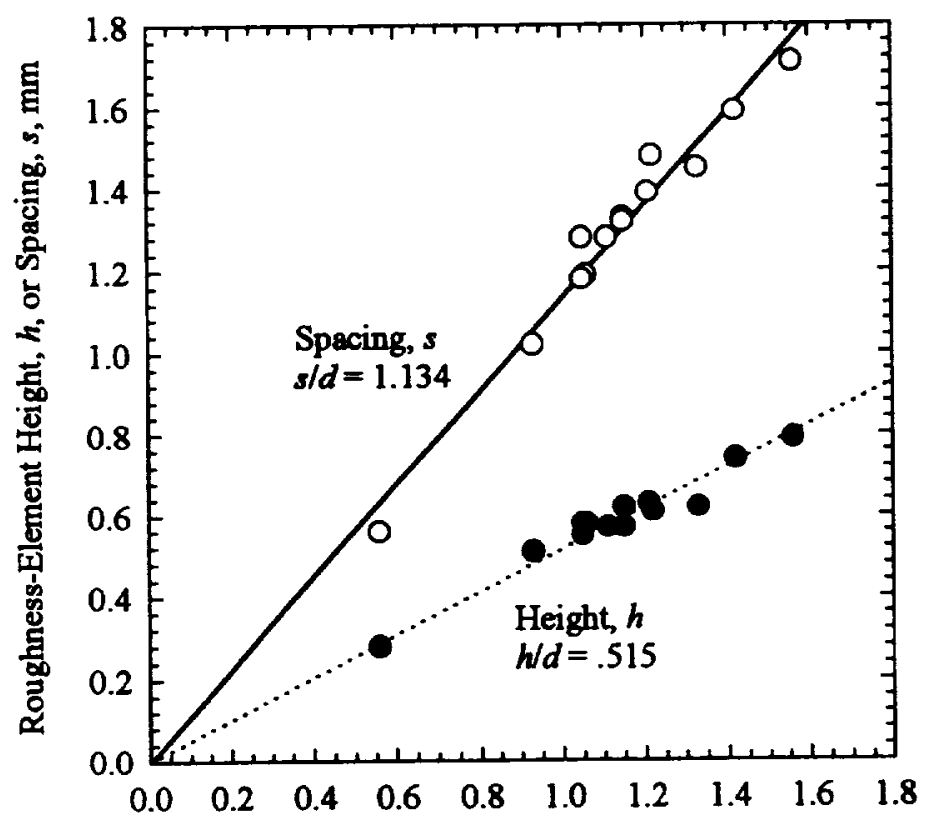

Roughness Element Diameter, $d, \mathrm{~mm}$

Figure 2. Correlations Between the Roughness Features. Data from Shin $^{3}$.

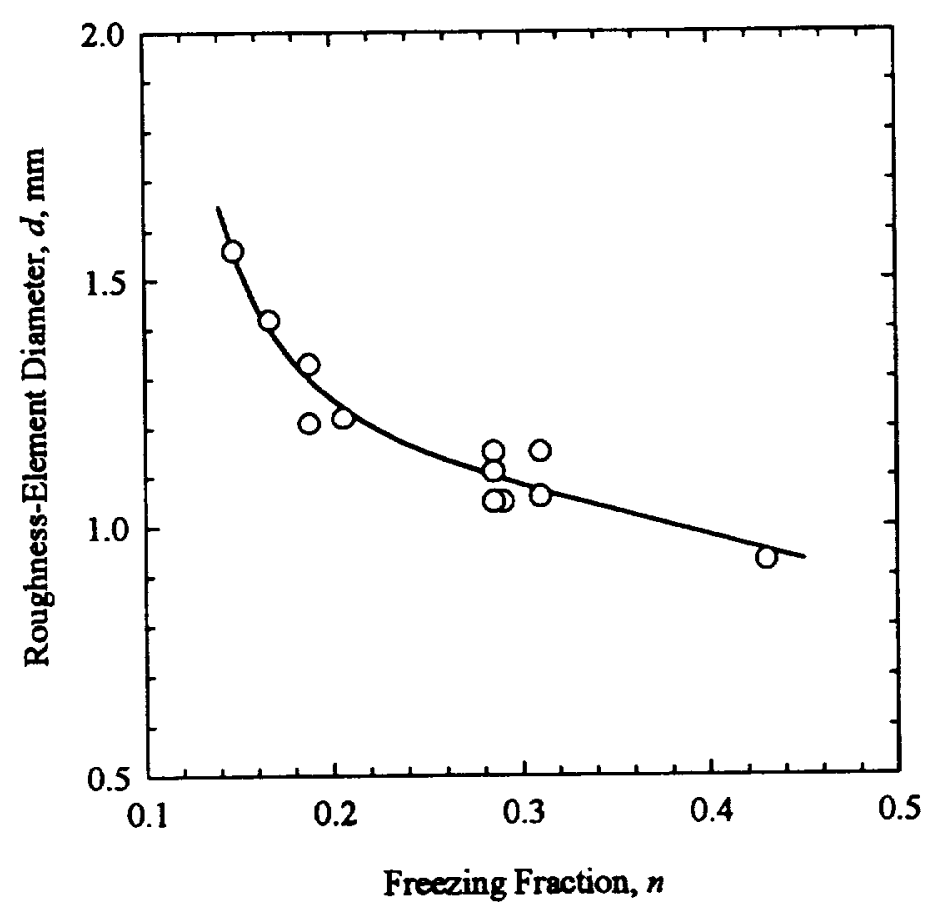

Figure 4. Effect of Freezing Fraction on Roughness Size. Accumulation Parameter Greater Than .1. Data from Shin ${ }^{3}$.

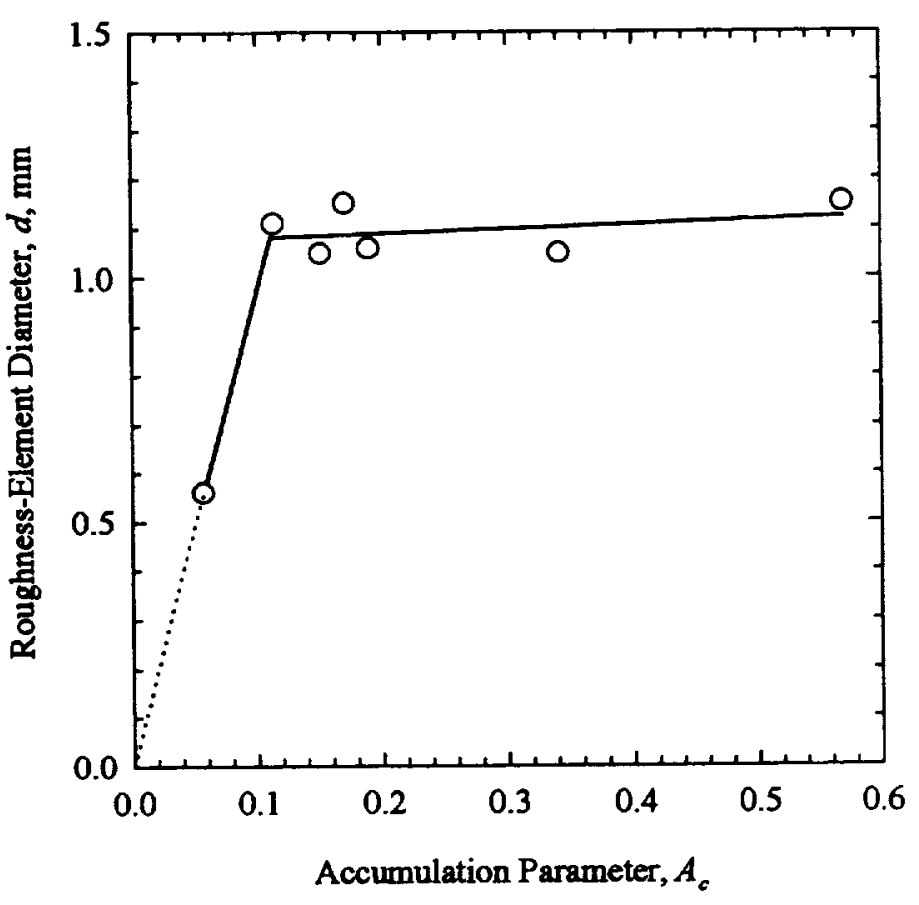

Figure 3. Effect of Accumulation Parameter on Roughness Size. Freezing Fraction, $3 \pm .015$. Data from $\mathrm{Shin}^{3}$.

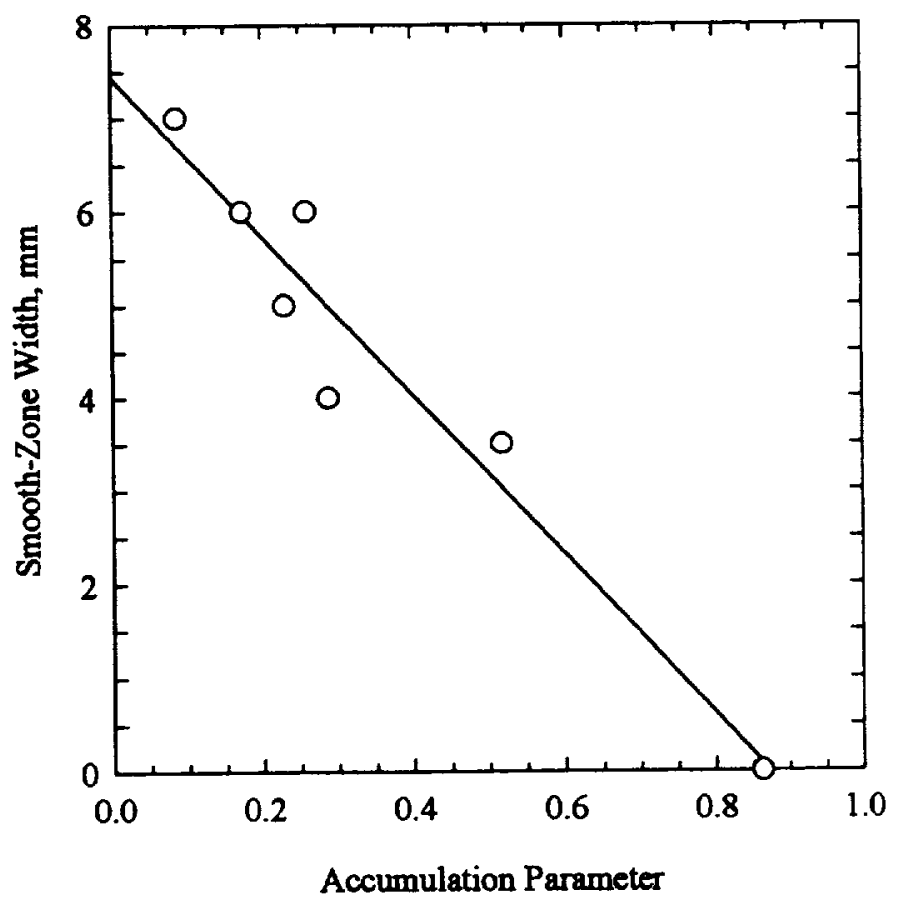

Figure 5. Effect of Accumulation Parameter on Smooth-Zone Width. Freezing Fraction, $.3 \pm .015$. Data from $\mathrm{Shin}^{3}$. 


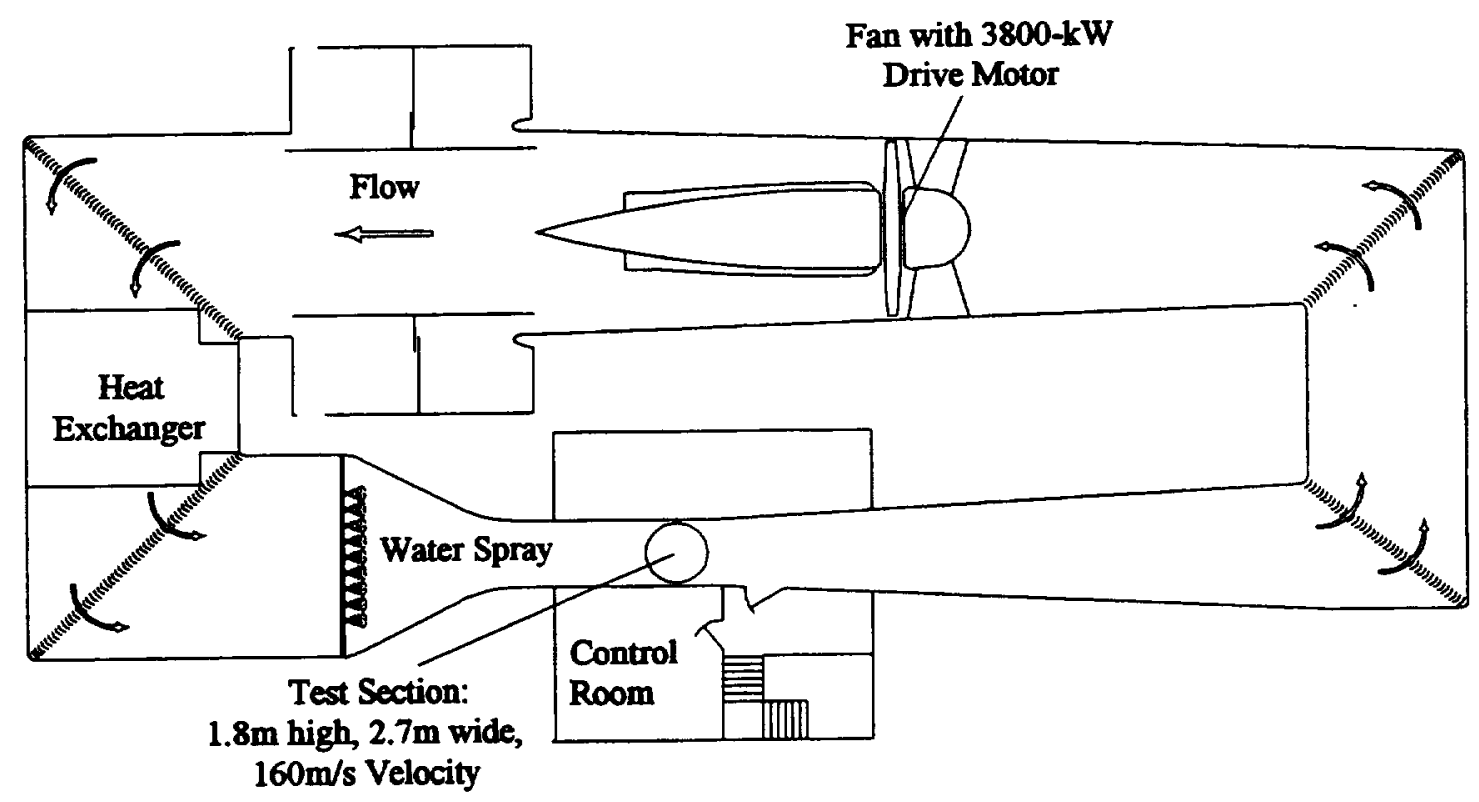

Figure 6. NASA Lewis Icing Research Tunnel (IRT).

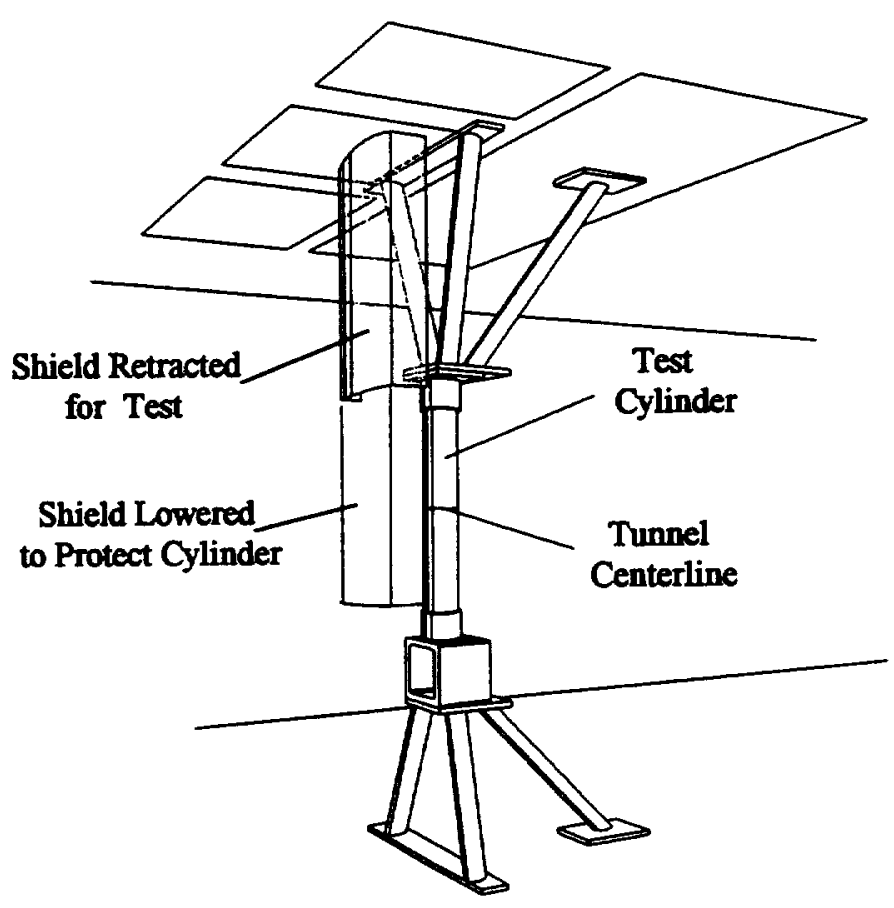

Figure 7. Test Cylinder and Shield Mounted in IRT. 


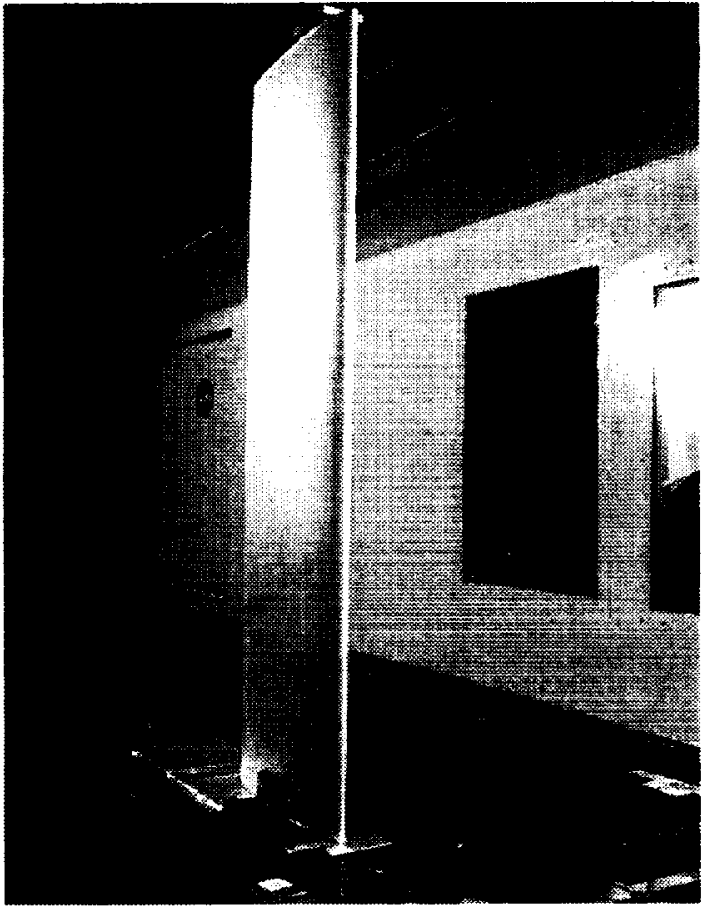

(a) Airfoil Installed in IRT Test Section.

Figure 8. 53.3-cm-chord NACA 0012 Airfoil.

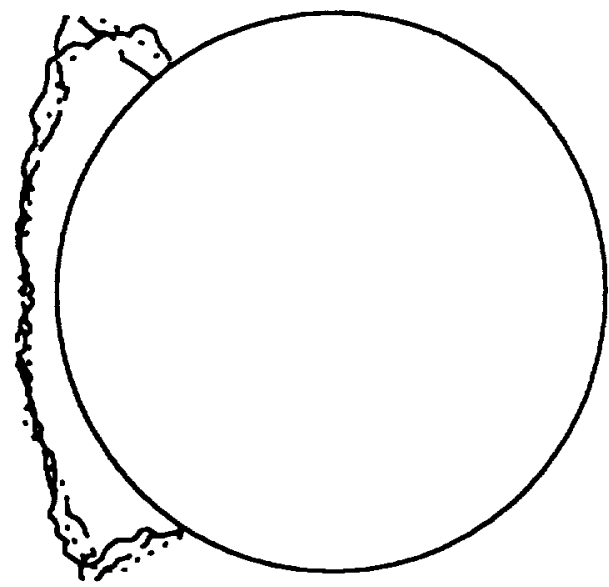

\section{Spray}

(a)

Initial $(1 / 2 \mathrm{~min}): L W C=1 \mathrm{~g} / \mathrm{m}^{3}, n=.20$ Final $(91 / 2 \mathrm{~min}): L W C=.5 \mathrm{~g} / \mathrm{m}^{3}, n=.35$

- - Full $(10 \mathrm{~min}): \quad L W C=.5 \mathrm{~g} / \mathrm{m}^{3}, n=.35$ Full $(10 \mathrm{~min}): \quad L W C=.5 \mathrm{~g} / \mathrm{m}^{3}, n=.35$ (Repeat.)

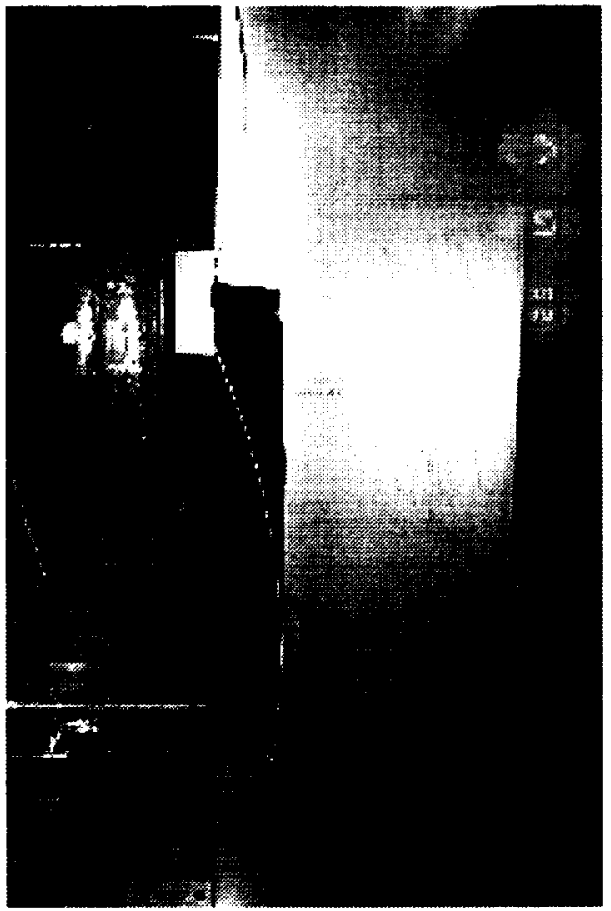

(b) Fabric Shield in Place on Leading Edge of Airfoil.

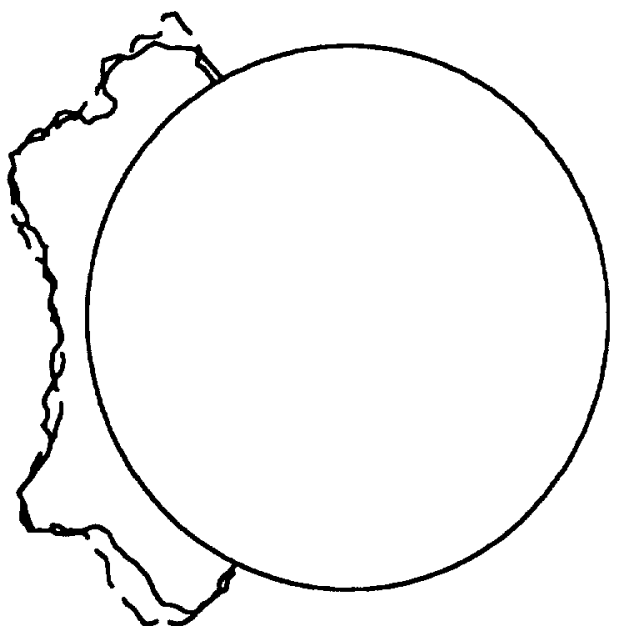

Spray

(b) Initial $(1 / 2 \mathrm{~min}): L W C=.5 \mathrm{~g} / \mathrm{m}^{3}, n=.35$ Final $(91 / 2 \mathrm{~min}): L W C=1 \mathrm{~g} / \mathrm{m}^{3}, n=.20$

- - Full $(10 \mathrm{~min}): \quad L W C=1 \mathrm{~g} / \mathrm{m}^{3}, n=.20$

Figure 9. Effect of Initial LWC on Final Ice Shape for Cylinder. Cylinder Diameter, $7.6 \mathrm{~cm}$ ( $3 \mathrm{in}$ ). $V=67 \mathrm{~m} / \mathrm{s}(150 \mathrm{mph}), t_{*}=-4^{\circ} \mathrm{C}\left(24^{\circ} \mathrm{F}\right), M V D=20 \mu \mathrm{m}$. 


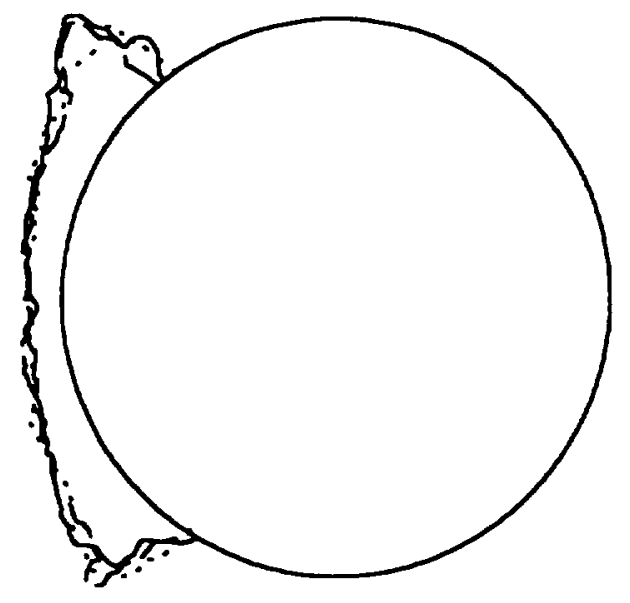

(a)

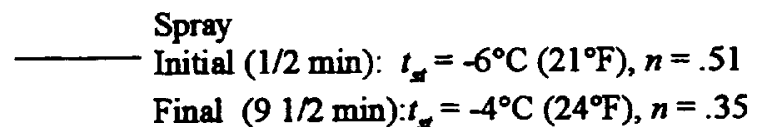

- - - Full $(10 \mathrm{~min}): t_{s}=-4^{\circ} \mathrm{C}\left(24^{\circ} \mathrm{F}\right), n=.35$

Full $(10 \mathrm{~min}): t_{s}=-4^{\circ} \mathrm{C}\left(24^{\circ} \mathrm{F}\right), n=.35$ (Repeat)

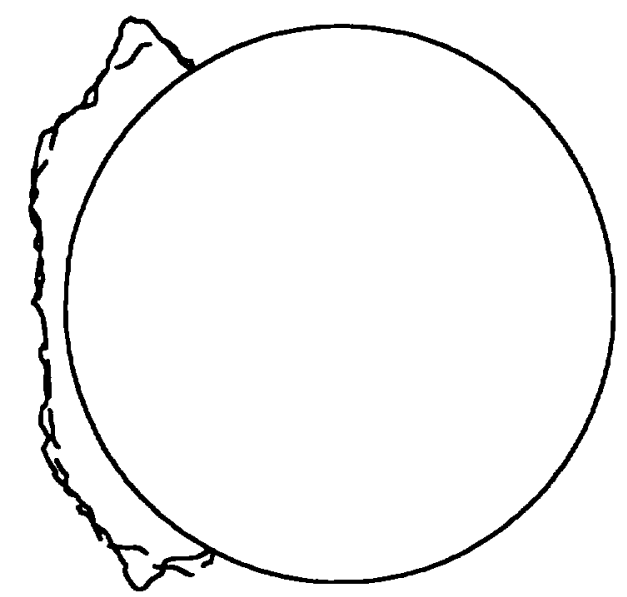

(c) Spray Initial $(1 / 2 \mathrm{~min}): t_{s}=-6^{\circ} \mathrm{C}\left(21^{\circ} \mathrm{F}\right), n=.51$ Final $(91 / 2 \mathrm{~min}): t_{s}=-3^{\circ} \mathrm{C}\left(26^{\circ} \mathrm{F}\right), n=.24$

- - Full $(10 \mathrm{~min}): \quad t_{x}=-3^{\circ} \mathrm{C}\left(26^{\circ} \mathrm{F}\right), n=.24$

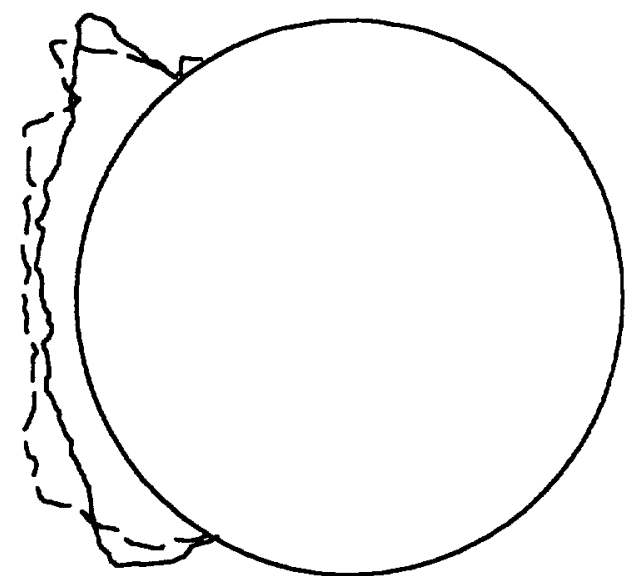

(b) Spray Initial $(1 / 2 \mathrm{~min}): t_{s t}=-4^{\circ} \mathrm{C}\left(24^{\circ} \mathrm{F}\right), n=.35$ Final $(91 / 2 \mathrm{~min}): t_{s}=-6^{\circ} \mathrm{C}\left(21^{\circ} \mathrm{F}\right), n=.51$ - - Full $(10 \mathrm{~min}): \quad t_{s}=-6^{\circ} \mathrm{C}\left(21^{\circ} \mathrm{F}\right), n=.51$

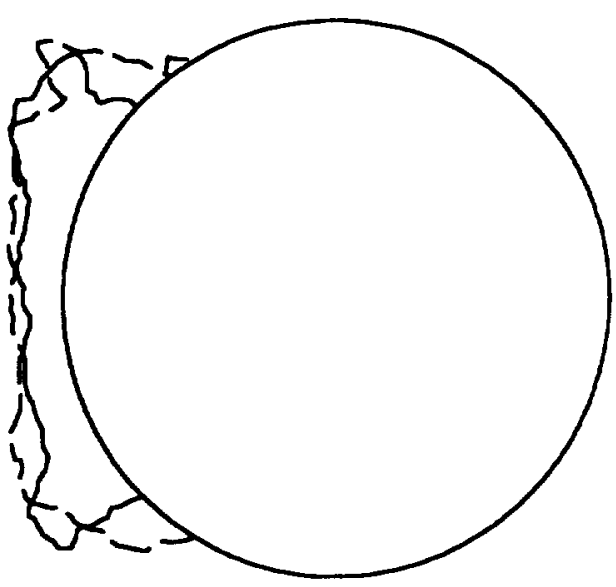

Figure 10. Effect of Initial Temperature on Final Ice Shape for Cylinder. Cylinder Diameter, $7.6 \mathrm{~cm}$ ( $3 \mathrm{in}$ ). $V=67 \mathrm{~m} / \mathrm{s}(150 \mathrm{mph}), M V D=20 \mu \mathrm{m}, L W C=.5 \mathrm{~g} / \mathrm{m}^{3}$. 


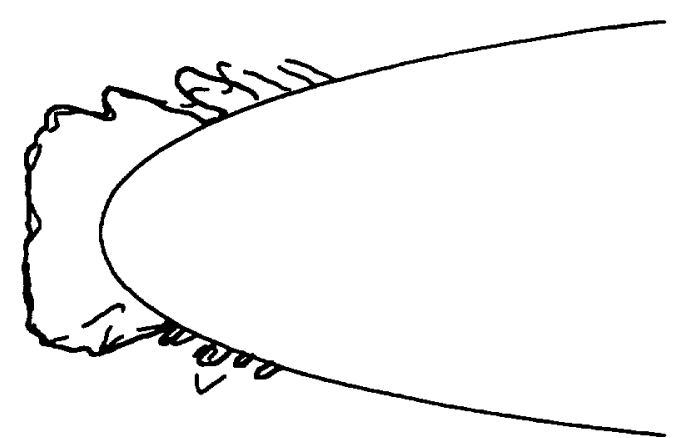

Initial $(1 / 2 \mathrm{~min}): t_{x}=-3^{\circ} \mathrm{C}\left(26^{\circ} \mathrm{F}\right) ; n=.27$

Final $(91 / 2 \min ): t_{s}=-6^{\circ} \mathrm{C}\left(21^{\circ} \mathrm{F}\right) ; n=.58$

— Full $(10 \mathrm{~min}): \quad t_{*}=-6^{\circ} \mathrm{C}\left(21^{\circ} \mathrm{F}\right) ; n=.58$

(a) Tests with $V=67 \mathrm{~m} / \mathrm{s}(150 \mathrm{mph}), M V D=20 \mu \mathrm{m}$ and $L W C=.5 \mathrm{~g} / \mathrm{m}^{3}$.

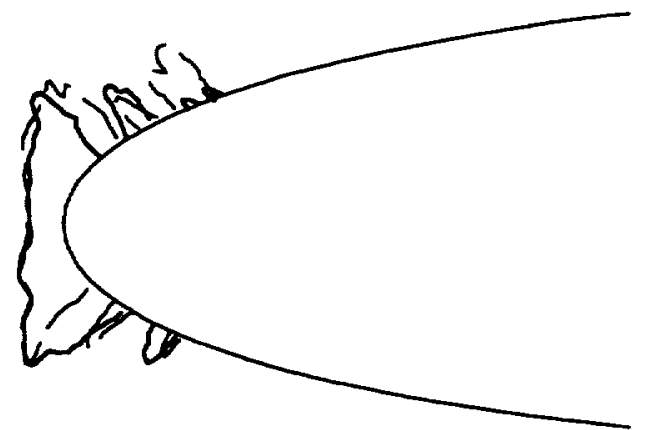

Initial ( $1 / 2 \mathrm{~min}): V=67 \mathrm{~m} / \mathrm{s}(150 \mathrm{mph}) ; n=.58$ Final (9 $1 / 2 \mathrm{~min}): V=89 \mathrm{~m} / \mathrm{s}(200 \mathrm{mph}) ; n=.40$

- Full $(10 \mathrm{~min}): \quad V=89 \mathrm{~m} / \mathrm{s}(200 \mathrm{mph}) ; n=.40$

(b) Tests with $t_{s}=-6^{\circ} \mathrm{C}\left(21^{\circ} \mathrm{F}\right), M V D=20 \mu \mathrm{m}$ and $L W C=.5 \mathrm{~g} / \mathrm{m}^{3}$.

Figure 11. Effect of Initial Spray on Final Ice Shape for Airfoil. NACA 0012 Airfoil With Chord, $53.3 \mathrm{~cm}$ (21 in). 

Public reporting burden for this collection of information is estimated to average 1 hour per response, including the time for reviewing instructions, searching existing data sources, gathering and maintaining the data needed, and completing and reviewing the collection of information. Send comments regarding this burden estimate or any other aspect of this collection of information, including suggestions for reducing this burden, to Washington Headquarters Services, Directorate for Information Operations and Reports, 1215 Jefferson Davis Highway. Suite 1204, Arlington, VA 22202-4302, and to the Office of Management and Budget, Paperwork Reduction Project (0704-0188), Washington, DC 20503.

\begin{tabular}{|l|l|l|}
\hline 1. AGENCY USE ONLY (Leave blank) & 2. REPORT DATE & 3. REPORT TYPE AND DATES COVERED
\end{tabular}

\begin{tabular}{|l|l|l}
\hline & January 1997 & Technical Memorandum \\
\hline
\end{tabular}

4. TITLE AND SUBTITLE

5. FUNDING NUMBERS

Characterization of Ice Roughness From Simulated Icing Encounters

6. AUTHOR(S)

WU-548-20-23

David N. Anderson and Jaiwon Shin

7. PERFORMING ORGANIZATION NAME(S) AND ADDRESS(ES)

National Aeronautics and Space Administration

Lewis Research Center

Cleveland, Ohio 44135-3191

8. PERFORMING ORGANIZATION

REPORT NUMBER

E-10606

9. SPONSORINGMONITORING AGENCY NAME(S) AND ADDRESS(ES)

National Aeronautics and Space Administration

Washington, DC 20546-0001

NASA TM- 107400

AIAA-97-0052

\section{SUPPLEMENTARY NOTES}

Prepared for the 35th Aerospace Sciences Meeting \& Exhibit sponsored by the American Institute of Aeronautics and Astronautics, Reno, Nevada, January 6 10, 1997. Responsible person, David N. Anderson, organization code 5840, (216) 433-3585.

12a. DISTRIBUTION/AVAILABILITY STATEMENT

12b. DISTRIBUTION CODE

Unclassified - Unlimited

Subject Category 02

This publication is available from the NASA Center for AeroSpace Information, (301) 621-0390.

13. ABSTRACT (Maximum 200 words)

Detailed measurements of the size of roughness elements on ice accreted on models in the NASA Lewis Icing Research

Tunnel (IRT) were made in a previous study. Only limited data from that study have been published, but included were the roughness element height, diameter and spacing. In the present study, the height and spacing data were found to correlate with the element diameter, and the diameter was found to be a function primarily of the non-dimensional parameters freezing fraction and accumulation parameter. The width of the smooth zone which forms at the leading edge of the model was found to decrease with increasing accumulation parameter. Although preliminary, the success of these correlations suggests that it may be possible to develop simple relationships between ice roughness and icing conditions for use in iceaccretion-prediction codes. These codes now require an ice-roughness estimate to determine convective heat transfer. Studies using a 7.6-cm-diameter cylinder and a 53.3-cm-chord NACA 0012 airfoil were also performed in which a 1/2min icing spray at an initial set of conditions was followed by a $9-1 / 2-$ min spray at a second set of conditions. The resulting ice shape was compared with that from a full 10 -min spray at the second set of conditions. The initial ice accumulation appeared to have no effect on the final ice shape. From this result, it would appear the accreting ice is affected very little by the initial roughness or shape features.

14. SUBJECT TERMS

Aircraft safety; Icing; Ice roughness

15. NUMBER OF PAGES

14

16. PRICE CODE

A03

17. SECURITY CLASSIFICATION OF REPORT

Unclassified

18. SECURIY CLASSIFICATION
OF THIS PAGE
Unclassified

19. SECUAITY CLASSIFICATION OF ABSTRACT Unclassified

NSN 7540-01-280-5500 